\title{
KARAKTERISTIK WAJAH GURU YANG DISUKAI BERDASARKAN PERSPEKTIF MURID SEKOLAH DASAR
}

\author{
Gumgum Gumelar* \\ Mirdas Al-Asy 'Ary** \\ * Program Studi Psikologi, Universitas Negeri Jakarta \\ ** Program Studi Psikologi, Universitas Negeri Jakarta
}

DOI: https://doi.org/10.21009/JPPP.051.02

\author{
Alamat Korespondensi: \\ ggumelar@unj.ac.id \\ mirdasofficial@gmail.com
}

\begin{abstract}
In addition to the teacher must have the quality of academic competence, quality and a good pedagogic competence also exists in non-verbal behavior components face. The characteristics of teacher's face is divided into four types: Anomalous Face, Baby Face, Emotion Face and Familiar Face. This research is descriptive research, data retrieval technique using the Likert Scale, Guttman Scale and Manipulation Cchecks for participants control never see facial characteristics of the teachers presented earlier. In data retrieval, facial characteristics of teachers compared with other teachers face characteristics. Based on the perspective of primary school students in the research sample, the result is the characteristic of the teacher's face Familiar Face menservants and characteristic facial Emotion Face female teachers have the highest value. Result shows that familiar face characteristics for male teachers and emotion face characteristics for female teachers have the highest scores.
\end{abstract}

Keywords

facial characteristics, teacher, education

\section{Pendahuluan}

Era globalisasi yang ditandai dengan persaingan kualitas dan mutu, menuntut untuk senantiasa bersaing dalam berbagai bidang dan sektor dalam meningkatkan kompetensinya. Hal ini ditandai dengan pentingnya upaya peningkatan kualitas pendidikan, sehingga pendidikan dapat menjadi sarana dalam membangun dan mengembangkan karakter bangsa. Sebagai salah satu penentu keberhasilan dibidang pendidikan, guru dituntut memiliki kualitas dan mutu yang baik

Pendidikan di Indonesia terus berkembang baik lembaga profit atau non-profit dan terus meningkatkan kualitasnya. Peningkatan kualitas pendidikan juga di lontarkan oleh Menteri Pendidikan dan Kebudayaan Republik Indonesia Muhadjir
Effendy dalam rapat kerja bersama Komisi $\mathrm{X}$ DPR RI, Penekanan pada upaya peningkatan kualitas pembelajaran di semua jenjang dan jalur pendidikan, baik negeri maupun swasta, dengan kesenjangan kualitas yang semakin kecil (www.kemendikbud.go.id, 02/09/2016). Belajar adalah perubahan perilaku yang relatif permanen yang berasal dari pengalaman dan tidak bisa dinisbahkan ke keadaan tubuh temporer seperti keadaan yang disebabkan oleh sakit, keletihan atau obat-obatan (Hergenhahn \& Olson, 2008). Mengajar pada dasarnya merupakan suatu usaha untuk menciptakan kondisi atau sistem lingkungan yang mendukung dan memungkinkan untuk berlangsungnya proses belajar. Murid atau anak didik adalah salah satu komponen manusiawi yang menempati posisi sentral dalam proses 
belajar-mengajar. Murid sebagai yang ingin meraih cita-cita, memiliki tujuan dan ingin mencapainya secara optimal (Sardiman, 2011). Proses pendidikan ditempuh dengan kegiatan belajar mengajar yang memiliki peran dan tujuan oleh anak didik dalam menyelesaikannya.

Guru merupakan unsur penting di dalam keseluruhan sistem pendidikan. Menurut UU No. 14 tahun 2005 bahwa guru merupakan pendidik profesional dengan tugas utama mendidik, mengajar, membimbing, mengarahkan, melatih, menilai, dan mengevaluasi peserta didik pada pendidikan anak usia dini jalur pendidikan formal, pendidikan dasar, dan pendidikan menengah. Peran guru dalam aktivitas pembelajaran yaitu sebagai kolektor, inisiator, fasilitator, pembimbing, pengelola kelas, mediator, supervisor dan elevator. (Djamarah, 2005).

Dewasa ini, kualitas pendidikan di Indonesia masih rendah. Hal ini terbukti melalui hasil penelitian mengenai kualitas kompetensi guru bahwa hasil Uji Kompetensi Guru (UKG) ada 192 guru dari 1,6 juta guru yang memperoleh nilai di atas 90. Sementara nilai rata-rata UKG yang guru dapatkan hanya 56 (Jawa Pos, 27 April 2016). Menurut UNESCO pada tahun 2016 minat baca yang dimiliki peserta didik di Indonesia sebesar $0,001 \%$ dapat dilihat bahwa dari 1000 orang hanya satu orang yang memiliki minat baca. Kemudian dalam "Most Littered Nation In The World" yang dilakukan oleh Central Connecticut State University pada Maret 2016, Indonesia menduduki peringkat negara ke-60 dari 61 terkait minat membaca. Artinya Indonesia menduduki peringkat kedua sebelum terakhir (www.kompas. com, 29 Agustus 2016).

Dalam hal pemerataan pendidikan, Indonesia memiliki kualitas yang belum baik dan merata. Hal ini dibuktikan oleh UNESCO pada tahun 2012 bahwa Indonesia menduduki peringkat ke64 dari 120 negara berdasarkan penilaian $E d u$ cation Development Index (EDI) atau Indeks Pembangunan Nasional. Total nilai EDI yang didapat tersebut diperoleh dari rangkuman perolehan yang memiliki empat kategori penilaian, yaitu angka partisipasi pendidikan dasar, angka melek huruf pada usia 15 tahun ke atas, angka partisipasi menurut kesetaraan gender, angka bertahan peserta didik hingga kelas $\mathrm{V}$ sekolah dasar (UNESCO, 2012). Berdasarkan hal di atas,
Indonesia harus terus meningkatkan kualitas pendidikan. Peningkatan kualitas pendidikan dalam berbagai aspek, seperti fasilitas, sarana dan prasarana, kompetensi guru baik dalam kompetensi internal dan kompetensi eksternal.

Anak didik pada jenjang sekolah dasar berada pada tahapan operasional konkret, dalam perkembangan afektifnya anak didik sudah dapat mengonservasi perasaan, perkembangan keinginan dan mulai menumbuhkan otonomi berpikir. Kemudian, anak didik sudah dapat mengembangkan pemikiran mereka sendiri berdasarkan prinsip kebaikan dan keadilan sehingga mereka mampu melihat keadaan melalui berbagai sudut pandang (Papalia, 2014). Dengan demikian, diharapkan anak didik dalam memberikan penilaian ataupun persepsi terhadap guru dapat mewakili perasaan, keinginan dan pemikirannya yang sesuai dengan keadaan yang terjadi.

Persepsi adalah proses mengatur dan mengartikan informasi sensoris untuk memberikan makna (King, 2010). Persepsi menurut Yufiarti dan Gumelar (2013) adalah proses organisme menginterpretasikan dan mengorganisir sensasi untuk menghasilkan suatu pengalaman yang penuh arti. Rakhmat (2011) memandang persepsi sebagai pengalaman tentang objek, peristiwa, atau hubungan-hubungan yang diperoleh dengan menyimpulkan informasi dan mengartikan pesan. Kemudian, persepsi juga dipandang sebagai proses individu dalam mengenali objek-objek menggunakan alat indra (Sabri, 2006). Oleh karena itu, persepsi anak didik terhadap guru dapat diperoleh melalui pengalaman-pengalaman dalam proses kegiatan belajar ataupun kehidupan sehari-hari.

Sikap adalah suatu reaksi evaluatif yang menyenangkan atau tidak menyenangkan terhadap sesuatu atau seseorang (Eagly \& Chaiken, 2005). Oleh karena itu, seseorang mungkin memiliki suatu sikap negatif, sikap netral dan sikap positif terhadap sesuatu ataupun terhadap seseorang (Myers, 2010). Anak didik setelah memersepsikan guru dapat memberikan sikap terhadapnya, meliputi sikap negatif, sikap netral dan sikap positif untuk kemudian memunculkan perilaku anak didik terhadap guru tersebut.

Perilaku adalah suatu kegiatan atau aktivitas organisme (makhluk hidup) yang bersangkutan (Notoatmodjo, 2007). Selanjutnya, perilaku 
menurut Skinner (1938) merupakan respon atau reaksi seseorang terhadap stimulus atau rangsangan dari luar. Faktor dari perilaku individu dipengaruhi oleh tiga komponen yakni (1) sikap, (2) norma subjektif, (3) kontrol yang dipersepsi dari hal tersebut memunculkan niat untuk berperilaku dan kemudian berperilaku. Dengan demikian, setelah anak didik memiliki sikap terhadap gurunya maka akan menghasilkan dan memunculkan perilaku terhadap guru maupun lingkungannya.

Menurut Livingston (2001), beberapa orang lebih menilai orang lain melalui penampilan mereka. Pentingnya penampilan guru juga disampaikan oleh Mohd Khairi guru Sekolah Kebangsaan di Malaysia, penampilan guru penting dan kemudian murid akan semangat untuk belajar, guru juga akan menjadi contoh terutama dalam aspek kerapian diri (www.sinarharapan.com, 4/4/2017). Dengan berpenampilan sopan, rapi, menarik, serta sesuai dengan norma yang berlaku tentu akan membuat orang yang melihatnya merasa nyaman, khususnya siswa (Ahmadi, 2003). Guru yang menarik dapat menjadi daya tarik tersendiri dalam ketertarikan anak didik terhadap guru karena daya tarik fisik merupakan karakteristik eksternal yang mempengaruhi perilaku nyata dan penampilan fisik telah menarik perhatian terlebih dahulu sebelum perilaku yang lain muncul (Baron \& Byrne dalam Malikus, 2005). Penampilan maupun daya tarik fisik guru memiliki perananan penting dan membuat orang yang melihatnya merasa nyaman.

Menurut Cherepanova (2002) guru dapat ditinjau melalui kompetensi pedagogis, di dalamnya terbagi menjadi komponen inti dan komponen eksternal. Komponen inti mencakup konsep diri, gambaran diri, kharisma dan kompetensi profesionalitas sedangkan komponen eksternal mencakup visual image (gaya berjalan, gaya berpakaian, gaya rambut, gaya posisi tubuh, makeup, aksesoris, parfum), perilaku verbal (suara dan mood), perilaku non-verbal (tingkah laku, gestur, dan muka), dan gambaran informasi. Lahey (2012) menjelaskan bahwa aspek-aspek ketertarikan meliputi kesukaan atau hubungan sosial, tugas dan rasa hormat, dan fisik atau penampilan. Oleh karena itu, guru selain harus memiliki kompetensi akademik, kualitas dan mutu yang baik juga perlu didukung dalam kompetensi pedagoginya. Dalam hal ini kompetensi pedagogic guru secara spesifik adalah wajah gurunya.

Gibson (1979) menjelaskan bahwa wajah seseorang dapat memberikan informasi adaptif tentang interaksi sosial mereka. Misalnya, wajah 'imut' dari bayi dapat memunculkan pendekatan respon protektif (Berry \& McArthur, 1986; Zebrowitz, 1997); wajah marah memunculkan penghindaran dan respon defensif (Balaban, 1995; Marsh, Ambady, \& Kleck, 2005). Wajah seseorang menyimpan banyak informasi seperti ketika seseorang sedih, senang, takut dan gugup terlihat dari wajah (Amda \& Fitriyani, 2016). Karakteristik merupakan ciri yang secara alamiah melekat pada diri seseorang yang meliputi seperti umur, jenis kelamin, ras/suku, pengetahuan, agama/kepercayaan (Caragih, 2013). Secara khusus Zebrowitz dan Montepare (2010) menjelaskan bahwa karakteristik wajah sebagai berikut Anomalous Face, Baby Face, Emotion Face dan Familiar Face.

Kompetensi guru diharapkan dapat menciptakan kondisi pembelajaran yang efektif untuk dapat mengantarkan peserta didik ke sebuah tujuan, yaitu menciptakan proses pembelajaran yang efektif dan menyenangkan (Mulyasa, 2005). Persepsi anak didik terhadap karakteristik wajah guru juga dapat dihasilkan dari pengalamanpengalaman dalam jenjang pendidikan sebelumnya. Oleh karena itu, setelah anak didik memersepsikan guru berdasarkan karakteristik wajah, dapat memunculkan sikap dan perilaku.

Berdasarkan hasil survei pada tempat populasi penelitian, dapat disimpulkan bahwa ada kecenderungan murid dalam kegiatan belajar mengajar memperhatikan penampilan guru yang mengajarnya terutama karakteristik wajah guru. Gambaran karakteristik wajah guru inilah yang perlu dilakukan penelitian berdasarkan perspektif murid sekolah dasar karena minimnya penelitian serupa di Indonesia. Oleh karena itu, penting untuk mengetahui "Gambaran Karakteristik Wajah Guru yang Disukai Berdasarkan Perspektif Murid Sekolah Dasar". Penelitian ini merupakan bagian dari penelitian yang lebih besar mengenai pengaruh ornamen-ornamen fisik (pakaian, suara, gaya komunikasi, gaya mengajar, dll). 


\section{Metode Penelitian}

Tipe penelitian ini adalah penelitian deskriptif, variabel penelitian ini adalah karakteristik wajah guru. Dalam penelitian ini menggunakan populasi terjangkau, populasi dalam penelitian ini adalah murid sekolah dasar yang berada di kelurahan Pondok Kelapa Jakarta Timur. Teknik sampling yang dilakukan adalah non probability sampling, dengan pengambilan sampel yang digunakan adalah quota sampling. Adapun kriteria sampel adalah (1) Berusia 10-12 tahun, (2) Berjenis kelamin laki-laki dan perempuan, (3) Murid Sekolah Dasar di kelurahan Pondok Kelapa Jakarta Timur.

Teknik pengumpulan data dalam penelitian ini menggunakan kuesioner yang diberikan secara langsung kepada partisipan. Dalam mendeskripsikan karakteristik wajah yang disukai menggunakan jenis skala Guttman, tipe karakteristik wajah tersebut dipasang-pasangkan untuk di bandingkan dengan tipe karakteristik wajah lainnya. Pertanyaan yang diajukan adalah gambar mana yang kamu sukai yang hasil jawabannya berupa gambar 1 atau gambar 2. Kemudian setelah menentukan gambar yang disukai, dilihat kembali seberapa suka dengan gambar yang dipilih melalui rating score dengan jenis skala Likert berupa Sangat Suka (SS), Suka (S), Tidak Suka (TS) dan Sangat Tidak Suka (STS).

Manipulasi perlu dicek karena dapat memverifikasi kesuksesan atau keberhasilan manipulasi kondisi atau situasi yang dimaksud oleh peneliti (Myers \& Hansen, 2002). Pada penelitian ini dilakukan manipulasi cek berbentuk stimulus familiarity dan stimulus pemahaman partisipan dalam bentuk pertanyaan. Stimulus familiarity untuk memastikan apakah partisipan mengenali wajah yang diberikan. Pertanyaan yang diajukan "Apakah kamu pernah melihat orang-orang tersebut sebelum mengerjakan soal ini?". Peneliti berasumsi apabila partisipan mengenali wajah yang diberikan atau menduga wajah orang-orang yang diberikan dikenali, persepsi partisipan akan bias. Dalam hal ini, persepsi partisipan sudah tidak hanya berdasarkan bentuk wajah, melainkan juga dipengaruhi aspek-aspek lain yang dimiliki orang yang diduga partisipan mengenali wajah orangorang yang ditampilkan.

Manipulasi cek yang berbentuk stimulus pemahaman partisipan dilakukan untuk mencari tahu seberapa paham partisipan dalam penelitian ini. Prosedur manipulasi cek ini dilakukan dengan asumsi bahwa partisipan paham akan pasangan gambar yang disajikan. Melalui pertanyaan "Apakah kamu kesulitan dalam membedakan gambar tersebut?", "Seberapa paham kamu dengan pertanyaan yang diberikan?" dan "Seberapa mudah kamu mengerjakan soal tersebut?" yang telah disediakan pada lembar jawaban. Pertanyaan-pertanyaan manipulasi cek diberikan pada akhir setiap pertanyaan perbandingan pasangan gambar diberikan.

\section{Hasil Penelitian dan Diskusi}

Sebelum instrumen digunakan untuk pengambilan data final, terlebih dahulu dilakukan proses uji validitas dan reliabilitas. Untuk pengujian validitas pada penelitian ini melalui expert judgment dilakukan kepada seseorang yang ahli dalam hal ini. Untuk reliabilitas instrumen ini sebesar 0,532 atau dapat dikatakan cukup reliabel jika disesuaikan dengan kaidah yang dibuat oleh Guildford. Reliabilitas didapatkan melalui hasil uji coba yang dilakukan pada salah satu sekolah tempat populasi. Penelitian dilakukan di SDN 03, SDN 04, SDN 06, SD Islam Assa'adah, Madrasah Ibtidaiyah Al-Hidayah di Kelurahan Pondok Kelapa Jakarta Timur.

Sebelum data diolah ke tahap selanjutnya, harus melewati uji manipulasi cek. Hasil manipulasi cek stimulus pemahaman pertanyaan, melaporkan bahwa 142 partisipan (95\%) paham terhadap pertanyaan yang diberikan dan manipulasi cek stimulus pemahaman membedakan gambar, melaporkan bahwa 130 partisipan (87\%) paham dalam membedakan gambar yang disajikan. Hasil manipulasi cek stimulus familiarity dari 150 partisipan yang menjawab pertanyaan tersebut, 126 partisipan (84\%) mengaku tidak pernah melihat gambar-gambar yang disajikan. Partisipan yang melaporkan pernah melihat gambar- gambar yang disajikan dalam penelitian, dapat memunculkan efek subjektivitas yang dapat mempengaruhi persepsi partisipan terhadap stimulus, sehingga data 
tersebut tidak diikutsertakan dalam proses pengolahan data.

Pengolahan data melalui statistika deskriptif, dalam data yang diperoleh menggunakan Skala Guttman didapatkan melalui perbandingan pasangan gambar seluruh karakteristik wajah guru. Perbandingan pasangan gambar dilakukan sebanyak dua belas kali kepada seluruh karakteristik wajah guru. Adapun hasilnya karakteristik wajah guru familiar face laki- laki dan karakteristik wajah guru emotion face perempuan menjadi karakteristik wajah guru yang disukai oleh sampel penelitian.

Data yang diperoleh dalam Skala Likert didapatkan dengan mengetahui seberapa suka dengan gambar yang dipilih dalam rentang Sangat Suka (SS), Suka (S), Tidak Suka (TS), dan Sangat Tidak Suka (STS). Rating skor yang didapatkan diolah menggunakan bantuan program aplikasi Statistical Package of Social Science (SPSS) for Windows versi 16 berupa statistika deskirptif dan diperoleh nilai mean masing-masing karakteristik wajah guru, yaitu Familiar Face laki-laki memiliki nilai mean 5.71, Emotion Face laki- laki memiliki nilai mean 1.69, Baby Face laki-laki memiliki nilai mean 4.22 dan Anomalous Face laki-laki memiliki nilai mean 2.98 Familiar Face perempuan memiliki nilai mean 5.92, Emotion Face perempuan memiliki nilai mean 7.21, Baby Face perempuan memiliki nilai mean 4.58 dan Anomalous Face perempuan memiliki nilai mean 1.03. Berdasarkan hasil pengolahan data Skala Likert, diketahui bahwa karakteristik wajah guru familiar face laki-laki dan karakteristik wajah guru emotion face perempuan memiliki nilai mean paling tinggi diantara karakteristik wajah guru lainnya.

Data deskriptif seluruh murid pada setiap perbandingan pasangan gambar diketahui bahwa karakteristik wajah guru laki-laki familiar face lebih disukai pada perbandingan pasangan gambar ke-1, ke-2 dan ke-3, karakteristik wajah guru lakilaki baby face lebih disukai pada perbandingan pasangan gambar ke-4 dan ke-6, karakteristik wajah guru laki-laki anomalous face lebih disukai pada perbandingan pasangan gambar ke-5. Selanjutnya, karakteristik wajah guru perempuan emotion face lebih disukai pada perbandingan pasangan gambar ke-7, ke-10 dan ke-11. Karakteristik wajah guru perempuan baby face lebih disukai pada perbandingan pasangan gambar ke-8 dan ke- 12. Selanjutnya, karakteristik wajah guru perempuan familiar face lebih disukai pada perbandingan pasangan gambar ke-9. Dengan demikian, murid lebih meyukai karakteristik wajah guru laki-laki familiar face dan karakteristik wajah guru perempuan emotion face hal ini dilihat bahwa karakteristik wajah guru tersebut memiliki skor lebih besar dalam perbandingan pasangan gambar.

Karakterisik wajah guru yang menjadi pilihan siswa-siswi dalam penelitian ini didapatkan mean 5.71/12 pada familiar face perempuan, mean 1.69/11 pada emotion face perempuan, mean 4.22/12 pada baby face perempuan dan mean 2.98/11 pada anomalous face perempuan. Selanjutnya, mean 5.92/12 pada familiar facel perempuan, mean $7.21 / 12$ pada emotion face perempuan, mean $4.58 / 12$ pada baby face perempuan dan mean $1.03 / 9$ pada anomalous face

perempuan. Sesuai dengan yang dikatakan Gibson bahwa wajah dapat memberikan informasi adaptif tentang interaksi sosial yang mereka lakukan. Misalnya, wajah 'imut' dari bayi dapat memunculkan pendekatan respon protektif (Berry \& McArthur, 1986; Zebrowitz, 1997); wajah marah memunculkan penghindaran dan respon defensive (Balaban, 1995; Marsh, Ambady, \& Kleck, 2005). Kemudian dapat disimpulkan bahwa siswa-siswi Sekolah Dasar dikelurahan Pondok Kelapa Jakarta Timur lebih memilih karakteristik wajah guru laki-laki familiar face dan karakteristik wajah guru perempuan karena karakteristik wajah guru tersebut memiliki nilai skor yang paling besar dalam data perbandingan pasangan gambar maupun nilai mean yang paling tinggi hal ini juga didukung dengan hasil analisis 
Gumgum Gumelar

Mirdas Al-Asy 'Ary

data crosstab diantara karakteristik wajah guru lainnya.

\section{Kesimpulan}

Dari hasil penelitian dan pengolahan data yang dilakukan dapat menggambarkan karakteristik wajah guru, yang terbagi ke dalam empat tipe yakni familiar face, baby face, emotion face dan anomalous face pada laki-laki dan perempuan. Dalam pengolahan data deskriptif didapat bahwa karakteristik wajah emotion face perempuan dan karakteristik wajah familiar face pada laki- laki menjadi pilihan yang paling disukai dengan memiliki nilai mean paling tinggi di antara karakteristik wajah yang lainnya. Dengan demikian, dapat disimpulkan kedua karakteristik wajah guru tersebut adalah karakteristik wajah guru yang disukai dari perspektif murid sekolah dasar di kelurahan Pondok Kelapa Jakarta Timur.

\section{Daftar Pustaka}

Bafadal, Ibrahim. (2004). Manajemen Peningkatan Mutu Sekolah Dasar dari Sentralisasi menuju Desentralisasi. Jakarta: Bumi Aksara.

Baron, R. A. \& Byrne, D. (2003). Psikologi Sosial Jilid 5 (edisi 10). Jakarta: Erlangga.

Brehm, S. S., Miller, R. S., Perlman, D., \& Campbell, S. M. (2002). Intimate Relationships, 3rd ed. New York: McGrawHill.

D' Evans \& Zarale O. (1999). Introducing Evolution Pshchology. Cambridge: Kun Books ltd.

Dixson, A. F. (2009). Sexual Selection and the Origins of Human Mating Systems. New York: Oxford University Press.

Djamarah, S. B. (2005). Guru dan Anak Didik dalam Interaksi Edukatif: Suatu Pendekatan Teoritis Psikologis. Jakarta: PT. Rineka Cipta.
Ells, T. J., Dunn, A. K., Sergeant, M. J., \& Davies, M. N. (2009). Multiple Signals in Human Mate Selection: A Review and Framework of Integrating Facial and Vocal Signals. Journal of Evolutionary Psychology, 111139.

Evans, S. (2008). The Male Voice: an Evolutionary Perspective. Newcastle: Nortumbria press. Paper.

Evans, S., Neave, N., \& Wakelin, D. (2006). Relationships Between Vocal Characteristics and Body Size and Shape In Human Males: An Evolutionary Explanation for A Deep Male Voice. Biological Psychology, 72, 160-163.

Feinberg, D. R. (2008). Are Human Faces and Voices Ornaments Signaling Common Underlying Cues to Mate Value? Evolutionary Anthropology, 17, 112-118.

Field, A. (2009). Discovering Statistics Using SPSS 3rd Ed. British: Sage Publications Ltd.

King, A. L. (2013). Psikologi Umum: Sebuah Pandangan Apresiatif (Buku 1). Jakarta: Salemba Humanika.

Laley, B. U. (2012). Psychology on Introduction (11ed). New York: The Mc Grow Hill. Companies, Inc.

Mosdkuft, T. (2016). The Assuptium (s) of Normality.

Musfah, J. (2011). Peningkatan Kompetesi Guru melalui Pelatihan dan Sumber Belajar Teori dan Praktik. Jakarta: Kencana.

Myers, D. G. (2012). Psikologi Sosial (Edisi 10, Buku ke-2). Jakarta: Salemba Humanika.

Mynbayeva, A. \& Yessenova, K. (2016). Dishitguishing Features of Teacher Image and Faculty Member's Image: Comarative Study. 
Papalia, Diane. E. (2014). Menyelami Perkembangan Manusia. Jakarta: Salemba Humanika.

Plutchik, R. (1994). The Psyshology and Biology of Emotion. New York: Hasper Collins College Publisher.

Polnay, L. \& David, H. (1993). Community Paediatrics 2nd. London: Churchill Livingstone.

Puts, D. A., Gaulin, S. J., \& Verdolini, K. (2006). Dominance and The Evolution of Sexual Dimorphism In Human Voice Pitch. Evolution and Human Behavior, 27, 283296.

Rangkuti, A. A. \& Wahyuni, L. D. (2016). Modul Analisis Data Penelitian Kuantitatif Berbasis : Classical Test Theory and Item Response Theory (Reasch Model).

Rangkuti, A. A. (2013). Statistika Parametik dan Nonparametik dalam Bidang Psikologi dan Pendidikan.

Santrock, J. W. (2014). Psikologi Pendidikan (Edisi 5, Buku Ke-2). Jakarta: Salemba Humanika.

Senati, L., Yulianto, A., \& Setiadi, B. N. (2015). Psikologi Eksperimen. Jakarta: Indeks.

Slamet. (2003). Belajar dan Faktor-Faktor yang Memengaruhinya. Jakarta: PT. Rineka Cipta.
Sukmadinata, N. S. (2003). Landasan Psikologi Proses Pendidikan. Bandung: PT. Remaja Pusdakarya.

Thalib, S. B. (2010). Psikologi Pendidikan Berbasis Analisis Empiris Aplikatif. Jakarta: Kencana.

Tiolina, S. (2012). Pengaruh Nada Suara Perempuan terhadap Persepsi Attractiveness Perempuan. (Skripsi). Jakarta: Universitas Indonesia.

Usman, M. U. (2003). Menjadi Guru Profesional. Bandung: PT. Remaja Pusdakarya.

Watsoon, D. \& Clark, L. A. (1994). The PANAS X. The University of Lowa.

Yufiarti \& Wahyuni, L. D. (2013). Pengantar Ilmu Pendidikan. Jakarta: Fakultas Ilmu Pendidikan, UNJ.

Yufiarti \& Gumelar, G. (2013). Sejarah dan Dasar-Dasar Psikologi. Jakarta: OCHD Offset.

Zuckerman, M., \& Miyake, K. (1993). The Attractiveness Voice: What Makes it So? Journal of Nonverbal Behavior, 17, 119130. 